folk/ed. Derg, 2020; 26(1): 73-86

DOI: $10.22559 /$ folklor.1163

\title{
Afro-Türkler: Temsiliyet, Gelenek ve Kimlik ${ }^{*}$
}

\author{
Afro-Turks: Representation, Tradition and Identity
}

\section{Müge Akpınar*}

\section{Öz}

Bu çalışma, Afro-Türkler özelinde temsillerin ve geleneklerin kimlikle ile olan ilişkisini sorunsallaştırmaktadır. Kimlik meselesi, temsiliyet ve gelenek ile birlikte incelenmekte; Afro-Türk topluluğunun dünüyle bugününün bağını kurarken kölelik geçmişinin izinden gidilmektedir. İzmir'e bağlı Hasköy, Yeniçiftlik ve Çırpı köylerinde bir yıllık katılımlı gözlem yapılarak ve derinlemesine görüşmeler yürütülerek gerçekleştrilen etnografik araştırma ile tamamlanan yüksek lisans tezinden uyarlanan bu çalışma, temsillerde yer bulan ayrımcılığı sorgulamakta; Afrika diasporasının kölelik ile tarihsel ilişkisini incelemekte ve topluluğun geleneklerinde meydana gelen değişimi araştırmaktadır. Bu şekilde aynı zamanda kolektif belleğin temsiliyet, gelenek ve kimlik üzerindeki etkisi de kendini göstermektedir. Silikleşen ve kaybolan gelenekler sonucunda, Afro-Türkler arasındaki kimliklenme sürecinde birleştirici etno-kültürel kimlikten ve kolektif bellekten ziyade ten rengi sembolik anlamını korumaktadır. Çalışmada, İzmir merkezli Afrikalılar Kültür, Dayanışma ve Yardımlaşma Derneği'nin gelenekleri canlandırma ve kolektif belleği tazeleme misyonu ile AfroTürklerin etno-kültürel kimliğinin (yeniden) inşa edildiği ileri sürülmektedir.

Anahtar sözcükler: Afro-Türkler, temsiliyet, gelenek, geleneğin yeniden inşası, kimlik, kolektif bellek

Geliş tarihi (Received): 12 Mayıs 2019 - Kabul tarihi (Accepted): 05 Ekim 2019

* Bu çalışmaya mevzu bahis tartışmalar, kaynaklar ve alıntılar, 2016'da Ankara Üniversitesi Sosyal Bilimler Enstitüsü Sosyal Antropoloji Anablim Dalı'na teslim edilen ve Doç. Dr. Meryem Bulut danışmanlığında tamamladığım “Afro-Türkler'de Kimlik: Temsiliyet, Gelenek ve Kolektif Bellek” başlıklı basılmamış yüksek lisans tezimden alınmıştır.

** PhD Candidate Social and Cultural Anthropology Freie Universität Berlin. akpinar.muge@yahoo.com. ORCID ID 0000-0002-1112-4135. 


\begin{abstract}
This study problematizes how representations and traditions relate to identity with a particular focus on Afro-Turks. Analyzing identity along with representation and tradition, this study traces the history of slavery while constructing the bonds of Afro-Turk community's past and present. Drawing on a one-year ethnographic research based on participant observation and in-depth interviews conducted in Hasköy, Yeniçiftlik and Çırpı villages of İzmir, which culminated in a master's thesis, the present work questions the discrimination in representations, examines the historical relationship between the African diaspora and slavery, and explores changes in community's traditions. Given the fact that and community-specifc traditions faded away, not a uniting ethno-cultural identity but kinship relations laden with the symbolic meaning of skin colour have attained a determining role in the process of identity construction among Afro-Turks. It is argued that the etnho-cultural identity of Afro-Turks has been (re)constructed and by the African Culture, Solidarity and Cooperation Association's mission of revitalizing traditions and collective memory.
\end{abstract}

Keywords: Afro-Turks, representation, tradition, reconstruction of tradition, identity, collective memory

\title{
Giriș: "Siyah" temsiller
}

Dünyadaki "siyah” temsillerinde ülke farkı gözetmeksizin olumsuz çağrışımlara rastlamak mümkündür. Afrikalıların alt bir ırk ya da kimi zaman ayrı bir tür olarak tanımlandığı sunumlar, gazeteler ve televizyonda yer alan medya görselleri bunların başında gelmektedir. $\mathrm{Bu}$ tür haber ve sunumlar, Afrikalıları, hayvanlara daha yakın bir yerde konumlandırarak hem onları ayrı bir sınıflandırmaya tabi tutmakta hem de "beyaz" insanı hâkim kılan bir meşrulaştırmayı beraberinde getirmektedir. ${ }^{1}$ Hirschman'ın (2004) bahsettiği gibi irk kavramı her ne kadar geçerliliğini yitirmiş olsa da, DNA özellikleri açısından genetik fark bulunmayan "ırk" grupları arasında hiyerarşik bir sınıflandırmaya gitmek şüphesiz ki politik nedenler barındırmaktadır.

Bu politik nedenler, köleliğin yasal bir zeminde işleyebilmesinde kolaylaştırıcı etkenler olarak şekillenmiş; Hristiyanlığın Afrikalı paganlara karşı verilen mücadele içinde salık verdiği vaazlarla "beyaz" adamın üstünlüğü ilân edilmiştir. Bu üstünlüğün kurucu öğelerinden biri, Hristiyan inancına sahip beyaz adam kimliği olurken diğer bir kurucu öğesi ise modernite ile rasyonelleştirilmiş steril olma durumu olmuştur. ABD'de kölelik resmi olarak 1865 tarihinde yasaklanmış olsa da siyahlarla beyazların sosyal alanlarının ayrılmasının Sivil Haklar Hareketi'nin etkisiyle 1964 yılında onaylanan kanunla ortadan kaldırılmasına dek, modern-yabanıl, siyah-beyaz, temiz-pis gibi ikili karşıtlıklar uzun süre başta medya temsilleri olmak üzere gündelik hayat içindeki her temsilde kendini göstermiştir. Üzerilerine Afrikalı çocuk resimleri çizilen sabun kutuları, kirli olarak atfedilen siyah deri renginden arınmak için insanların kullanması mesajıyla piyasaya sürülmüştür (Hall, 2003). Bu durumun benzer bir örneği, Şubat 2015 - Şubat 2016 arasında bir yıl süreyle aralarında etnografik alan çalışması yürüttüğüm Afro-Türklere ulaşmak için ilk iletişim kurduğum kişi olan ve Afrikalılar 
Kültür, Dayanışma ve Yardımlaşma Derneği’nin başkanlığı yürüten Mustafa Olpak'ın² kendi derisine parmağını sürerek "kir"den kaynaklanan siyah rengi silmeye çalışanlar olduğunu anlatmasında karşıma çıkmıştır.

Yüksek lisans tezi olarak sonuçlanan, Afro-Türklerde kimlik sorunsalıyla yola çıktığım ve İzmir'in Hasköy, Yeniçiftlik ve Çırpı köylerinde bir yıl süreyle farklı sıklıklarla misafir olarak gerçekleştirdiğim katılımlı gözlemle yürüttüğüm etnografik alan çalışması kapsamında; etno-kültürel kimliği, sosyal inşa süreci sonunda şekillenen, çoklu ve dönüşümsel bir kategori olarak değerlendirdim. Çalışmaya başlarken bu sosyal inşanın kurucu öğesi olarak ayrımcılık pratiklerini de göz önünde bulundurarak ten rengini ele aldım. Etno-kültürel kimlik ile bağlantılı olarak ten renginin anlamlandırılmasını, aynı zamanda temsiliyet ve geleneklerin kimlikle olan ilişkisini incelemeye devam ettim.

Temsiliyet ve kimlik ilişkisinin kurulması anlamında, ten rengi ve kir arasında sembolik bir ilişki mevcuttur. Douglas'ın vurguladığı üzere "kirin olduğu yerde bir sistem var demektir" (2007: 59). Bu sistem, kirli ve temiz olanı ikili kategorilerde ayırma ve sinıflandırmayı beraberinde getirmektedir (Douglas, 2007). Douglas'ın işaret ettiği gibi kirli ve temizi ayırmada hijyene dayalı bir sistemden ziyade sembolik bir sınıflandırma söz konusudur. Bu örnek, kendi içinde ayrıca bir semiyotik analize tabi tutulabilir. Aynı şekilde Afrikalıların, ABD ve Avrupa sinema ve edebiyatındaki temsillerinde de modern-yabanıl, siyah-beyaz, temiz-pis gibi ikilikleri üzerinden resmedildiğinden bahsetmek mümkündür. Yine, "mülayim” siyah ev hizmetçileri, "atletik" siyahi sporcular ve onların abartılı temsillerinin taşıdığı benzer imalar söz konusudur (Hall, 2003).

Batı'da ikili karşıtlıkları pekiştiren ve Afrikalı olmayı ikincil bir insan türü olmaya indirgeyen temsiller, aynı zamanda ayrımcılığa uğrayan özneler olarak Afrikalıların zihinlerine; Fanon (2014) ve Du Bois’in (2007) “çifte bilinç” olarak kullandığı şekilde, kendi öz algılarıyla birlikte "beyaz"ların kendileri hakkında ne düşündüğünü düşünme tarzında eş zamanlı iki farklı bilincin oluşmasıyla yerleşmiştir. "Siyah”, der Fanon, "beyaz adamın ilk bakışıyla birlikte, kendi siyahlığının yükünü hissetmeye başlayacaktır hemen” (2014: 171). Ve dahas1, kendini beyazlarla özdeşleştirerek, beyaz adamın hal ve tutumlarını benimseyecektir (Fanon, 2014: 168). Fanon, siyahlar açısından beyazların sadece bir öteki değil aynı zamanda bir efendi olarak da görüldüğünü vurgulamaktadır (2014: 156).

\section{Türkiye'de "siyah" temsiller}

“Batı”daki temsillerle karşılaştırmalı olarak “Doğu”da ve Türkiye özelinde temsiliyet ve ayrımcılığa eğildiğimizde karşımıza çok da farklı bir tablo çıkmamaktadır. Türkiye'deki Afrikalı temsilleri "Arap bacı", "Gündüz feneri”3 (Olpak, 2013: 128) gibi kelimelerde vücut bulmaktadır. Yine "Arap kızı camdan bakıyor” anonim şarkısı da bu bağlamda ele alınabilir, TRT'nin siyah temsillerle ilgili olarak hazırladığı belgesellerinden birinin isminin bu şarkıyla aynı olması pek de şaşırtıcı değildir ${ }^{4}$. Mustafa Olpak bu şarkıda, genel kanının aksine, yağmuru bir evin içindeki pencereden dışarıya bakarak, yani ıslanmayarak, izleyen Afrikalı kız çocuğundan değil de; evin içinde onu izleyen çocuklara dışarıdan ıslanarak bakan Afrikalı k1z çocuğundan bahsedildiğini söylüyordu. ${ }^{5}$ 
Türkiye'de medya, edebiyat ve sinema alanındaki temsillerin Afrikalıların nasıl algılandığ 1 hakkında bize fikir vereceğini söylemek yanlış olmaz. Bir dönemin televizyon ve radyo programlarında "Arap bacı", "çikolata renkli sanatçı" gibi ifadeler ile anılan; filmlerde, dizilerde hizmetkâr olarak rol alan Afrikalıların hepimizin kulağında ve gözünde yer ettiği aşikârdır. Reşat Nuri Güntekin'in 1947 yılında kaleme aldığı Miskinler Tekkesi'nde İzmir Tamaşalık’taki Afrikalılar hakkında beyan edilen küçümseme ve acımayla karışık ifadeler olumsuz temsillerin bir göstergesidir:

Tamaşalık'ın ahalisi Afrika zencileridir. Konaklardan çıkarılmış yahut kaçmış sürü sürü Gülfidan bacılar ve onların erkekleri... Bunların güçlü, kuvvetlileri gündüzün şehirde incire, palamuda yahut dilenciliğe giderler; ihtiyar ve sakatlar kulübelerinin önünde, kızgın güneşin altında iri kertenkeleler gibi yarı çıplak yatarlardı. Tamaşalık’ta geceler de gündüzleri aratmayacak kadar sıcaktır. Gündüzün tepedeki dağın, hamam taşları gibi kızan kayalıkları, güneş batınca bu sıcağı ağır ağır aşağıya vermeye başlarlar ve mahallede Arapçıklar için adeta Sudan geceleri hüküm sürer ki, biçareleri buraya toplayan da belki budur (2014 [1947]: 51).

Yine, Halit Ziya Uşaklıgil'in sırasıyla 1934 ve 1950 yıllarında yazdığı Dilhoş Dadı hikâyesinde ve İzmir Hikâyeleri kitabında Afrikalı kadınların dadı olarak Afrikalı erkeklerin ise hizmetkâr olarak çalıştırıldığını görüyoruz. Uysal ve hizmet eden Afrikalı dadının transa geçtiği zaman efendisinin evinden uzaklaştırıldığını da görüyoruz. Uşaklıgil'in İzmir Hikâyeleri (2005 [1950]) kitabında Civelek Ziver, Ayni Tata ve İki Sima başlıklı hikâyelerde İzmir'de yaşayan Afrikalıların hayatlarından izlere rastlamak mümkündür. Civelek Ziver hikâyesinde Gudya Meseret abladan şöyle bahseder Uşaklıgil: "Gudye Meseret abla, iyice yaşlanmış, kıvırcık saçları ağarmış, gözleri bulanmış fakat dişleri hâlâ sağlam ve beyaz, ihtiyar bir kadıncıktı" (2005 [1950]: 158).

Uşaklıgil, zenci kadınların beyaz erkeklerle evlenmesinden doğan çocuklara, yani "açık" renklilere "çucana" denildiğini, bunların hiçbir zaman tam beyaz olmadığını; ancak, Habeşilerden daha açık bir renk aldıklarını söyler (2005 [1950]: 159). Uşaklıgil’in İzmir Hikâyeleri'inde Ayni Tata'nın isminin Arapça mı olduğu sorulmakta; Afrikalılara hem zenci hem siyahi hem de Arap denildiği belli olmaktadır. İki Sima hikâyesinde ise Şeyh Şemseddin ve Şeyh Bedreddin adlı Nakşibendi şeyhi iki ihtiyar kardeşin yanlarında zenci bir hizmetkârla yaşadıklarından bahsedilmektedir (Uşaklıgil, 2005 [1950]).

Boratav, siyahilerin yani Arapların, masallarda, halk hikâyelerinde ve gölge oyunlarında hem iyi karakter hem de kötü karakter temsilleriyle yer aldığını söylemektedir (1951: 83). İyi zenciler Hızır gibi tasvir edilirken; kötü zenciler ya derviş görünümündeki serserilerle ya da kurnaz yaşlı adamlarla temsil edilmektedir (Boratav, 1951:85). Birçok halk hikâyesinde siyahiler, zor durumda olanların yardımına koşan Hızır olarak anlatılmakta ve ne zamanki başı zor durumda olan biri “of” dese, o zaman ortaya çıkacaklarına inanılmaktadır (Boratav, 1951: 83). Gölge oyunlarında da Afrikalılar bulunmakta; Hacivat'ın kölesi çocuksu aksanı ve tavrıyla gülünç ve sonradan görme olarak temsil edilmektedir; saray hayatıyla ilgili şakalarda da benzer temsiller söz konusudur (Boratav, 1951: 83).

Boratav, halk hikâyelerinde Arap/zenci kılığına girmiş kahramanların da olduğunu söylemektedir (1951: 84). Bazı hikâyelerde de kendini Arap/zenci kılığında gizleyerek âşık oldukları kişinin kendisi hakkında ne düşündüğünü öğrenmeye çalışan sultanlar anlatılmaktadır; 
eğer âşık oldukları kişi onları Arapken bile seviyorsa sultanlar mutlu olup siyah olmadıklarını göstermektedirler (Boratav, 1951: 84). Bunun aynı zamanda 1rkçı bir tavra işaret ettiğini belirten Boratav (1951), bazı halk hikâyelerinde ırkçılığın çok daha sert bir şekilde karşımıza çıktığından bahsetmektedir; böylesi hikâyelerde zenciler lanetlenmiş ve barbar bir varlık olarak resmedilmektedir. Bunun Ali Cengiz Oyunu hikâyesinin birçok versiyonunda görülebileceğini söyleyen Boratav, örneğin bir zencinin sultanın kızlarını tek tek yediğinin ve bilmecesinin cevabını bilemeyenleri öldürdüğünün anlatıldığını dile getirmektedir (1951: 85).

\section{Kölelik ve Afro-Türkler}

Afro-Türkler, Osmanlı Devleti döneminde Hicaz, Basra ve Akdeniz köle ticaret yolları üzerinden bugünkü Türkiye sınırlarında yer alan bölgelere getirilen kölelerin torunlarıdır. Osmanlı'nın her döneminde köleler olmuştur; ancak, 19. yüzyıldaki Osmanlı köleciliği önceki dönemlerdekinden farklı olarak, ekseriyetle savaşlarda esir alınanların köleleştirilmesine değil; Kafkasya'dan ve Afrika'dan yapılan köle ticaretine dayanmaktadır (Şen, 2007: 73). Afrika'dan gelen kölelerin 19. yüzyılda artış nedenleri arasında, Mısır'ın 1820-22 yıllarında Sudan'1 işgal etmesi ve Osmanlı'ya Mısır'dan çok fazla köle gelmesi; Osmanlı'nın 1835'te Trablusgarp'ı tekrar işgal etmesiyle Afrika'nın iç bölgelerinden kölelerin getirilmesi ve 1869 yılında Süveyş Kanalı'nın açılmasıyla köle ticaretinin yoğun yapıldı̆̆ı şehirler arasında buharlı gemi ulaşımının sağlanması sıralanabilir (Erdem, 2013: 79). Amerikan İç Savaşı döneminde baş gösteren pamuk kıtlığı sırasında 1860'lı yıllarda Mısır'da tarım köleliği de görülmüştür (Toledano, 2007: 13).

Osmanlı'da Tanzimat dönemi ve sonrasındaki sosyal reformlar kapsamında 1846 'da İstanbul Esir Pazarı'nın kapatılması, 1857 Afrika'dan köle ticaretinin yasaklanması ve 1876'da Kanunu-i Esasi'nin ilanı ile ülke sınırlarına yeni kölelerin getirilmesi engellenmeye çalışılmıştır. 1857 tarihli yasaktan sonra Afrika'dan getirilen köleler azat edilirken, yasak öncesi gelmiş kölelerin durumunda ise herhangi bir değişiklik olmamıştır. 1882 ve 1883 'teki kanun tasarıları, 1889 Brüksel Kongresi'nin ardından çıkan karar ile 2. Meşrutiyet döneminde 1909'da çıkarılan aile düzenlemesi kararının hiçbiri Osmanlı' da köleliği resmi olarak kaldırmamıştır (Erdem, 2013).

Şaul, Osmanlı'ya çok geniş bir kültür coğrafyasından Afrikalı kölelerin getirildiğini, söylemekte; bugünkü Nijerya'nın kuzeyinde yer alan Hausa ülkesi kültürünün Türkiye'deki ve Ege adalarındaki Afrikalılar üzerinde etkisi olduğunu düşünmektedir (2015: 90). Şaul, Afrikalı kölelerin konuştukları dillerin, edebi eserlerde ve arşivlerde aktarılan kelimelere bakarak, Kuzey Nijerya ve Çad'da konuşulan Kanuri dili ile Batı Afrika'da yaygın olan Hausa dili olmasının kuvvetle muhtemel olduğunu söyler (2015: 101). Uşaklıgil'in Dilhoş Dadı (2010) [1934] hikâyesinde geçen Afnuca dilini, Afnuna kelimesiyle birlikte ele alan Şaul, Afnuna kelimesinin Hausalar için yaygın olarak kullanılan bir kelime olduğunu belirtir (2015: 101). Nitekim Dilhoş Dadı'nın baktığı çocuğun, dadısının bahsettiği büyük denizin Çad Gölü olduğunu düşünmesi (Uşaklıgil, (2010) [1934]: 102) boşa değildir.

Afro-Türklerin sanki sadece tek bir ülkeden bu topraklara gelmişler gibi Sudanlılar isminde etnik bir azınlık olarak kimi kaynaklarda yer aldığını görürüz. Mesela Soysü’nün (1992) "Sudanlılar" isimli kitap bölümünde konu bu şekilde ele alınmaktadır. Bu durum, araştırmam 
boyunca da çoğu kişinin atalarının Sudan'dan geldiğini söylemesiyle karşıma çıkmıştır. Bu durumda şüphesiz ki Mısır'ın 1820-1822 yılları arasında Sudan'1 işgal etmesi ve Sudan'dan yoğun bir köle ticaretine başlanması etkili olmuştur. Ancak, Sudan, Osmanlı' da köle ticaretinin yapıldı$\breve{g}$ ı bölgelerden sadece bir tanesidir. Afrikalı köleler arasında Akdeniz üzerinden, Hacca giderken köle getiren insanlar aracılığıyla Hicaz üzerinden ve de Hint Okyanusu köle ticareti aracılığıyla Basra Körfezi’nden özellikle Zanzibar Adası üzerinden gelenler vardır (Şaul, 2015: 94-95).

Kölelik geçmişi, Afro-Türklerin yaşadığı ekonomik ve sosyal sorunları günümüze taşımış ve sadece temsiliyet ve kimlik ilişkisinde değil; aynı zamanda sınıfsal konumlarını belirlemede ve bugünkü örtük veya açık ayrımcılık biçimlerinde kendini göstermeye devam etmiştir. Afro-Türkler, kendi kimliklerini doğrudan kölelikle özdeşleştirmeseler de, çoğunlukla yer aldıkları alt sınıf ile köleliğin tarihsel ilişkisi göz önünde bulundurulduğunda kimlik ve sınıf arasında sembolik olmaktan öte bir ilişki olduğu açığa çıkmaktadır. Köleliğin sosyoekonomik ve kültürel uzantıları, Afro-Türklerin bugünkü yaşamlarına ve etno-kültürel kimlik inşası sürecine etki etmektedir. Bir anlamda Türkiye toplumunun kara kutularından biri olarak kalmaya devam eden kölelik, Afro-Türklerin 1926 Medeni Kanunu ile vatandaş kabul edilmesiyle uygulama dışında kalmış ve BM'nin kölelik uygulamalarına benzer pratiklerin kaldırılması yönünde çıkardığı uluslararası kararnameyi 1964 tarihinde Türkiye’nin de onaylayarak kanunlaştırmasıyla resmi olarak yasaklanmıştır'.

\section{Yok olan geleneklerin izini bugün'de sürmek ${ }^{7}$}

Afro-Türkler arasındaki eski geleneklere dair özellikleri, görüştüğüm kişilerden genç olanlar bilmiyordu. İzmir’e bağlı, Hasköy, Yeniçiftlik ve Çırpı'da gerçekleştirdiğim katılımlı gözlem ve görüşmelerde yaşlı kişiler arasında dahi eski gelenekleri hatırlayan çok az kişi vard1. 2015 Ramazan Bayramı'nda Hasköy'e gittiğimde konuştuğum köyün en yaşlı kadını olan M., hastalığından dolayı bazı şeyleri çok net hatırlayamıyordu; ancak, uzun süre konuştuktan sonra çocukluğundan hatırladığı şeyleri benimle paylaşıyordu:

"Tin kiti tin ka tin kiti tin ka çalgı çalan ve kafasını sallayan Araplar varmış, biz onlardan değiliz... Kafalarını sallıyorlardı, burada yoktu başka yerlerdeydi. Nenemiz vardı, nenemiz diyoz biz gari, Cengi nene, kazık gibi küt diye kendinden geçip gidiyordu”.

Cengi ninenin ne zaman öldüğünü hatırlamıyordu M., çok oldu öleli diyordu sadece. Ben Cengi ninenin şifacı olup olmadığını sorduğumda ise şöyle diyordu:

"Şifasını bilmiyorum da... Çocukken gördüm, kafasını sallarken şarkısını söylerdim... İki değneği alıp karşı karşıya geçiyorlardı... Ahmalikum ficiniye diye şarkı söylüyorlard1. Çat çat değnekler birbirine çarparlar"...

M., bunun hangi günlerde yapıldığını sorduğumda bilmediğini söyledi, bayram ya da düğünle ilişkisi olup olmadığını da bilmiyordu. O kadar kaldı aklımda, diyordu. Hasköy’de kadın kadına oynuyorlardı, diyordu. "Ellerinde birer tane değnek, iki kişi, biri bir yana biri bir yana geçerkene çat çat değnekler birbirine çarparlar...” diye tekrarlıyordu. Eski gelenekler üzerine konuşmaya devam ettikçe M. şöyle diyordu: "Kızgın şişi yanağından geçiren varmış, da duydum ama görmedim, bizim burada yoktu." Bayılanlara sonra ne olduğunu sorduğumda ise M.: "kendi başına mı ayılıyor, biz o bayılınca kaçıyoruz öyle mi ayılıyor hatırlamıyorum” diyordu. Söylediği şarkının Arapça kötü bir manası olduğunu belirtiyordu, 
ama manasını hatırlamıyordu ve farklı Araplardan bahsediyordu: "O düğün çalan, kafasını sallayan Araplardan yok bizde... Öyle Arapça çalgı çalıp tin kiti tin ka tin kiti tin ka ede ede oynayan Araplar da varmış; kökü sapı nerede bilmiyorum”.

Çırpı'daki yaşlı M. ise, kendisine eski geleneklere dair neler hatırladığını sorduğumda, “eskiden daha fazla insan varmış. Arapların çoğu gitti. Hasköylü Araplar gelip burada toplanırlardı. Çırpı'da büyük bir ağacın altında toplanırdı Araplar” diyordu. Yaşı M., su kabağının çok eski bir çalgı olduğunu, onunla Hasköy'de oynandığını söylüyordu; kendi çocukluğunda gördüğünün davullar olduğunu belirtiyordu. Çocukluğundaki sünnet düğününe ilişkin olarak şunları anlatıyordu:

“Sünnet düğünümü hatırlıyorum. 10-12 yaşlarındaydım. Hasköy’ün Arapları hep buradaydı, bir ağaç vardı... Bütün bu avluyu kaplıyordu (hâlâ oturmakta olduğu evi ve bahçeyi kastederek) onun başında tavuklar yatardı, erkekler, davullar filan vardı... Çaybaşılı Karadana zurna çalgıcı olarak vardı."

Osmanlı'da Afrikalıların sahip olduğu dinsel öğeleri barındıran, pagan inanç ve gelenekler, İslam'a tezat teşkil ettiği için eleştirilmektedir ve cezaya çarptırılabilmektedir (Toledano, 2007: 237). Bu durum, İslam'ın hâkim olduğu bölgelerde bir tehdit unsuru olarak algılanmakta ve Afrikalı geleneklerinin şehirde ve kırsalda yaygınlaşması bu tehdit algısını arttırmaktadır (Toledano, 2007: 237- 238). Afrikalılar tasavvuf pratiklerini bünyelerine katarak daha dirençli hale gelmeye çalışsalar da İslam'dan uzaklaşılacağı korkusuyla Osmanlı yöneticileri törenleri engelleme girişiminde bulunmuşlardır (Toledano, 2007: 238). Örneğin Godyalar ve cemaatler arasında, devletin buyurduğu kayıt ve yerleştirme işlemlerini göz ardı ettiği gerekçesiyle, İstanbul'dan sürülenler olmuştur (Toledano, 2007: 238).

Erdem, Osmanlı devletinin Kolbaş/Godya örgütlenmesinden ve onların etkinliklerinden rahatsızlık duymuş olabileceğinden bahsetmektedir (2013: 219). Zira Godya ya da Kolbaş1 denen insanlar, örgütlenme ve iletişimi sağlıyordu (Şaul, 2015: 101). Bu rahatsızlık hem Afrikalıların eski pagan inançlarını Müslümanlık içinde devam ettirmeleri bakımından duyulmuş olabilir; hem de Kolbaşıların/Godyaların azat edilmiş köleler hakkında söz sahibi olması nedeniyle siyasal açıdan devlet tarafından tehlikeli bulunmuş olabilir (Erdem, 2013: 220). Godya kurumu, devlet yetkilileri tarafından engellemelerle ve yasaklamalarla karşılaşmış ve giderek zayıflamıştır. Hem Ortodoks İslam inancının pagan inanç ve ritüellerini dışlaması hem de 1925 'te Cumhuriyetin Tekke ve Zaviyeleri kapatarak laik devlet uygulamalarının benimsenmesi bu yasaklarda etkili olmuştur. Ortodoks İslam tarafından heretik olarak görülen godyalık, laik Cumhuriyet tarafından da devlet uygulamalarına ters ve modernleşme karşıtı olarak değerlendirilmiştir.

Modernleşmenin, Batı Aydınlanmasına içkin dikotomileri beraberinde getirmesi, Tanzimat dönemiyle birlikte Afrikalılar özelinde de görülmeye başlamıştır. Toledano'nun Dana Festivali konusunda Osmanlı elitinin bakış açısını yansıtan 1894 tarihli İzmir Hizmet gazetesinde yayınlanan bir yazı örneğinde gösterdiği gibi, bu kutlamayla dalga geçilmesi ve bunu yok etmenin etkili yolunun "halkın cahilliği”ni yok etmek olduğuna inanılması söz konusudur (2007: 236). Gazete yazısında bu festivali yapanların eğer ineğin kanı akıtılmazsa kafası kesik bir Afrikalının İzmir'e gelerek şehre bela ve hastalık getireceğine inandığı belirtilmekte; bu tarz hikâyelerin ciddiye alınmaması gerektiği yazmaktadır (Toledano, 2007: 236). Bu inanç ve kutlamalar üze- 
rinden Afrikalılar cahil olarak aşağılanmakta ve onların kutlamasına katılan "beyaz ahali”ye de şaşkınlık ve acımayla bakıldığı yazılmaktadır (Toledano, 2007: 236). Bu gazete yazısı, Osmanlı dönemindeki dikotomik temsilleri gün yüzüne çıkarmaktadır. Biz ve öteki ayrımı, beyaz ahali ve zenciler; medeniler ve vahşiler; ciddiler ve komikler; eğitimliler ve cahiller; mantıklılar ve gülünçler; aklı başında olanlar ve aklı başında olmayanlar, edepliler ve edepsizler ikili kategorileriyle kendini belli etmektedir (Toledano, 2007: 237).

Cumhuriyet döneminde Afrika gelenek ve kutlamaları 1925 Tekke ve Zaviyeler Kanunu ile yasaklanmıştır. Bu kanun, devletin uygun gördüğü dini ibadet biçimleri dışındakileri yasaklamış, Türkiye'deki Afrikalılar da bundan nasibini almıştır. Köylerde görüştüğüm kişiler arasında bu yasağın uzantılarının doğrudan tanıklarından sadece bir kişiye rastlayabildim. $\mathrm{Bu}$ kişi, 90 yaşın üzerinde olan H. idi. H. yaklaşık 12 yaşlarındayken Tulum köyünün arkalarında yer alan dağların yamacında kutlamalar yapıldığını ve civar köylerden birçok Afrikalının katıldığı bu törenlerden birinde jandarmanın coplarla saldırarak töreni dağıttığını aktarmıştır.

H., katılımlı gözlemi yaptığım üç köyden farklı bir güzergâhta oturuyordu. Ancak yaşı ve deneyimleri dolayısıyla bilgilerine ihtiyaç duyduğum için onunla derinlemesine görüşme yapmaya gitmiştim. H., araştırmam boyunca Godya (Godya) kelimesini ağzından duyduğum tek kişiydi. Hatırlaması için çok üstelemeyip biraz bekleyince, kendisi şöyle anlatıyordu:

Godya derlerdi be valla... Biz Urfalı Çiftliği’nden göçtük, geldik buraya. Anam Burgaz'dan (şimdileri Torbalı'ya bağlı olan Atalan) oraya gelin gelmiş. Ciddeli Ali derler dedeme. Hacı Ali Paşa dedemizi büyütmüş. Atalan' da çiftliği varmış Hacı Ali Paşa'nın dedemi burada büyütmüş, sonra Urfalı Çiftliği'ne gelmiş. Annem, Hacı Ali Paşa ülamesi Tahir Kızı Durdu.

H., ülamenin evlat demek olduğunu açıklıyordu ve babasının köle olup olmadığına dair bir şey demiyordu. Sadece babasının Menemen tarafından olduğunu belirtiyordu. Dana Bayramı ile ilgili olarak hatırladıklarını ise şöyle anlatıyordu:

“Gelirlerdi Urfalı’ya her ay erzak toplanırdı. Çuvaldızı (yanağı ve ağzı arasında bir yeri göstererek) buradan sokup buradan çıkarırlardı. Bir hafta aman gari ne oyun... Yeniçiftlik değil, Arapların çok oldukları bir yer vardı, dümbek çalarlardı, ayılana mı bakarsın bayılana mı bakarsın. Ben çocuktum. Urfalı'nın Urfalı olduğu zamanlardı. 11-12 yaşlarında vardım. Tulum yolundan giderkene sağ kolunun üstüne düşüyor, orada Fatma godyanin evi vardı. Orada gari kahkahalarla otururlard1, dümbek çalarlardı, ondan sonra tövbe yarabbi... Şimdi millet şeytanız di mi oraya öteberi koyarlardı gittiler mi una suya katıp bunlara onu verirlermiş... Yerlermiş onlar cinler... Gözümle görmedim bak neler geldi geçti şimdi oraya bak... Şimdi ne cinler ne şeytan... Koca köy oldu orası bak.”

Buradaki cinler kimdi bilmiyorum. Bu konuda bulabildiğim tek kaynak Boratav idi. Boratav, Afrikalıların şifacılarının cinlerle ilişkilendirildiğini ve tedavi için cinlerle iletişim kurduklarına inanıldığını söylüyor; aynı zamanda, Afrikalılar arasında cinlerden olduğuna inanılan ve hastalıklarda başvurulan kişiler olduğunu belirtiyordu (1984: 76).

Yaşı ve deneyimleri dolayısyla araştırma güzergâhından farklı bir köye giderek görüşme yaptığım diğer kişi olan Tulum'daki A. ise Dana Bayramı, sopalarla dans ve eski geleneklerle ilgili bir şey hatırlayıp hatırlamadığını sorduğumda şöyle demişti: 
"Ben hatırlamıyorum ama söyleyenler var. Eskiler hatırlar. Annelerimiz, komşularımız söylerdi, Urfalı köyünde Dana Bayramı yaparlarmış. Dağların arkasında. Eskiden oradalarmış. Sonradan oradan bu tarafa göçtüler. Şimdi yaşayan yok. Tulum'da yoktu Dana Bayramı (yanındakini kastederek) bunun nenesinin vard1, evinde onla bir çaldığı vardı. Senesinde kendi kendine çalarmış. Allah tarafından kendi kendine çalarmış. Biz giderdik, çocuğuz ya... Sorardık Selma bu ne diye, bu eskiden Araplar Dana Bayramı'nda böyle çalar, oynarlardı dedi biz bakardık... Diyordu sen de tıngırdat, ben ya korkardım ondan derdim, bakardım, gülerdi."

Bu konuşmada geçen ve her sene belli günlerde kendi kendine çalan şeyin, evde duvara asılı olan def olduğunu konuşma bittikten sonra anladım. A. sopalarla oynanan oyunu bilmiyordu; ancak, başka bir şeyden bahsediyordu:

"Büyükler anlatırdı, ben görmedim. Biz duyduk sadece. Dedemlerden de eskide ağzından şiş geçirenler varmış. Onları eskiden Sultan Hamit buraya getirmiş, köle olarak mı artık neydiyse. Tire'den Torbalı tarafına getirmiş... Çiftliklerde çalıştırmak için getirmişler, karın tokluğuna insanları çalıştırmışlar”.

A., "Bu taraflarda, Naime, Çırpı, Yeniçiftlik, Araplar çoktu, gari beyazlarla evlenerek az kaldık” dedi. Şimdi Tulum'da da Naime'de de 2-3 hane kaldığından bahsederek 20-30 yıl önce belki 15-20 belki daha fazla hane olduğunu; ancak şimdi göçle azaldığını ekledi.

H., derneğin düzenlediği Dana Bayramı'na hiç gitmemişti, Dana Bayramı'nı kendisine sorduğumda, "eskiden Urfalı' dakine bakardık" diyordu ve "şiş geçiriyorlardı" diye ekliyordu. Köydekilerden, şiş geçirenlerin cambazlar olabileceğini söyleyenler de olmuştu; ama, kimse kim olduklarından emin değildi. Ben de şiş geçirmenin herhangi bir kültürel pratikle bağlantısını bulamadım. H., uzunca düşünüp eskiden Arapların çok yaşadığg yeri hatırlıyordu ve Tire’ye doğru giderken Çatal olduğunu söylüyordu. Çatal, Tire'nin ötesinde, bugünkü Ödemiş-İzmir yolu üzerinde yer alıyordu. "Çok Arap vardı, onlar bizim gibi değillerdi, entari giyerlerdi, bayılana mı bakarsın ayılana mı bakarsın... Beli kuşaklı giyerlerdi bağlarlardı, şalvar bilmezlerdi” diyordu. Entarilerin rengini hatırlamıyor ama ayak bileğini işaret ederek “buraya kadar" uzanıyor diyordu. Bugün Torbalı'ya bağlı olan ve ismi Şehitler olarak geçen Meşhed'de de Arapların olduğundan bahsediyordu. H., geçmiş bayramlarla ilgili fotoğrafi olup olmadığını sorduğumda olmadığını söylüyordu ve Dana Bayramı'na ilişkin hatırladıklarını paylaşıyordu:

“Kalktı gari o, karakollar basmış; basmış değil bastı. Oynarlarken... Urfalı’ da oynuyorlard1. Jandarma geldi. Bize yasak ettiler. Bayılanlar tıss bayılıyorlardı. Valla iki tane cobu vurdular, ne ayılan ne bayılan kaldı... Subaşı karakolu".

Baskınla birlikte jandarmanın dövdüğü kişilerin akıbetinin ne olduğunu, hapse girip girmediklerini bilmiyordu H., sadece baskını ve dağıtılmayı hatırlıyordu. Godyaların kadın mı erkek mi olduğunu sorduğumda onu da hatırlamadığını söylüyordu. Ancak duyduğum Godyaların hepsi kadın ismi taşıyordu. H.'nin, paylaştıklarından hareketle, İzmir şehir merkezinde Dana Bayramı'nın yasaklanmasıyla Afrikalıların dağlık kırsal alanlara kaçarak ritüellerine devam ettiğini düşünebiliriz. Ancak elimizde bununla ilgili kesin tarihi bir bilgi olmadığından, bir dönem birbirinden ayrı olarak farklı merkezlerde Dana Bayramı'nın kutlanmaya ve geleneklerin yaşatılmaya devam ettiğini de düşünebiliriz. 
Bu baskın gibi engelleme ve yasaklamalar, Afro-Türklerin geçmişleriyle olan zayıf bağlarının tamamen kopmasını beraberinde getirmiştir. Bu anlamda kimlik, tam da görünmez olma hallerinin içinde yeni anlamlar kazanmış ve belki de varoluşsal bir sorun olmaktan çıkmıştır. Derneğin çabalarıyla eski geleneklere dair uygulamalar yaşatılmaya çalışılmakta; ancak, bu sürecin kalıcı olup olmayacağını zaman belirleyecek görünmektedir. Geleneklerin yeniden inşa edilmesi de diyebileceğimiz bu sürecin nasıl işleyeceği uzun vadede bize bir cevap sunacaktır. Kimlik temsillerinden geriye kalanlar ise bazen Kara Hasan, Kara Dana lakaplarında olduğu gibi, bazen Zenci soyadında ve "Kara" öneki alan soyadlarda ve bazen de İzmir'in çeşitli semt ve mahallelerinde rastlanan isimlerde Arap Hasan Mahallesi, Bahri Baba Parkı ve Susuz Dede Park1 ${ }^{8}$ örneklerinde görüldüğü gibi şimdiki zamana tutunmaya devam etmektedir.

\section{Sonuç yerine: Geleneklerin yeniden canlandırılması ve kimliklenme}

Afro-Türkler arasında Afro-Türk ifadesinin bir kimlik imleci olarak kullanılması oldukça yenidir. Bu terimin kullanımı, 2006 senesinde kurulan Afrikalılar Kültür, Dayanışma ve Yardımlaşma Derneği ile yaygınlık kazanmaya başlamıştır. Daha çok yeni nesil tarafından kullanılan bu ifade, eski kuşaklar arasında bir geçerliliğe sahip değildir. Türk ve Müslüman olarak kendilerini kabul eden toplulukta kimlik ifadesi olarak en sık kullanılan ifade Araptır. Aynı şekilde ten rengine göre açık Arap ve koyu Arap olarak adlandırılarak farklı renk skalasına tabi tutulanlar vardır. Etno-kültürel kimliğin farklılıkları da barındıran heterojen bir kategori olduğu, yaşlı neslin konuşmalarında ortaya çıkan "farklı Araplar" nitelendirmesiyle göz önünde bulundurmalıdır. Etno-kültürel kimlik tanımı yapmayı mümkün kılacak, değişime kapalı homojen bir birlikten ziyade farklılıkları barındıran; ancak, grubu bir arada tutan ortak dil ve yaşam tarzı alışkanlıkları gibi unsurlarla esnek bir bağlayıcılığa sahip olan ortak kültür, Afro-Türkler'de silikleşmiştir. Afro-Türkler arasındaki bağlayıcı unsurlar zamanla aşınmış ve topluluk ten renginin sembolik birleştiriciliği altında birbirine büyük ölçüde akrabalık bağıla bağlı kalmıştır. Yelvington'un (1991) etnik kimliği tanımlarken kullandığı "metaforik" akrabalık, bu toplulukta yerini gerçek akrabalığa dayalı "metaforik" bir etnik kimliğe bırakmış gibidir. Bu durum, zihinlerde ortak bir tasavvurla kurulan sembolik topluluk inşasından ziyade ten rengi ile korunan akrabalık ile desteklenen bir aidiyete işaret etmektedir.

Afro-Türklerin ortak bir anavatan imajından ziyade ortak bir ten rengi üzerinden aidiyet, temsiliyet ve kimlik ilişkisini kurduğunu söylemek daha yerinde olacaktır. Afro-Türklerde ten rengi, topluluk içinde siyah ve beyaz şeklinde homojen ve dikotomik kategoriler yerine ara kategorileri de kapsayacak şekilde bir sınıflandırma ile değerlendirilmekte; ayrımcılık ve aidiyet bağlamında kişilerin kendini siyah veya beyazın farklı tonlarına daha yakın veya uzak konumlandırması söz konusu olmaktadır.

Afro-Türklerin etno-kültürel kimliklerinin izinden giderken kırıntılarına rastladığım gelenekler, dünyanın birçok yerinde devam eden ve benzer öğeleri barındıran ritüelleri kapsamaktadır. Dünya üzerinde diğer ülkelerdeki Afrika diasporasında devam eden Afrika geleneklerinin bir kısmı, bugünkü Anadolu coğrafyasında da bir zamanlar devam ediyordu. Bu geleneklerin neden ve nasıl son bulduğu; başka türlü sormak gerekirse, diğer coğrafyalarda bu ritüellerin nasıl ayakta kaldığı bize etno-kültürel kimlik açısından önemli şeyler söylemektedir. Aynı zamanda bugün ritüellerin devam ettiği coğrafyalarla küresel bir etkileşim 
sonucu benzer gelenekleri Anadolu coğrafyasında tekrardan devam ettirmenin mümkün olup olmayacağını düşünmeye de sevk etmektedir.

Afro-Türklerin kendi etno-kültürel kimliklerini deneyimlemesinde ve diğer etnik gruplarla sınırlarını belirlemesinde etkili olan geleneklerden her yıl bahar ayında kutladıkları Dana Bayramı'na katılım azalarak 1950'lere kadar devam etmiştir. Afrikalı geleneklerinin giderek sönümlenmesiyle Dana Bayramı başta olmak üzere diğer birçok ritüel ve etkinlik unutulmuştur. 2006 yılında kurulan Afrikalılar Kültür, Dayanışma ve Yardımlaşma Derneği, gelenekleri canlandırmayı hedeflemekte ve aynı zamanda Afro-Türk kimliğini yeniden inşa etmeyi amaçlamaktadır. Dana Bayramı'nı Osmanlı İmparatorluğu'nun son döneminde ve İmparatorluk yıkıldıktan sonra organize eden Godya kurumundan bugün hiçbir eser kalmadığı için dernek bu kurumsal görevi misyon edinmiş durumdadır.

Türkiye'de etno-kültürel kimlik özelinde mücadele veren diğer topluluklara oranla daha görünmez olan Afro-Türkler çoğunluklar bu görünmezliği kabullenmiş görünmektedir. Elbette bu görünmez kılınmanın ardında Afrika'nın farklı ülkelerinden getirilen, aralarında dil ve gelenek bağı olmayan insanların köle olarak satıldığı bir tarihsel arka plan yatmaktadır. Görünmez kılınmanın devamını sağlayan koşullar, 1925 yılında Türkiye Cumhuriyeti tarafından Tekke ve Zaviyelerin kapatılması sonrasında Afrikalıların kendi geleneklerine temas etmesine izin verilmeyişi ile pekiştirilmiştir. Ulus devletin laiklik ve tek millet ilkeleri doğrultusunda idealleştirilen bir modernleşme üzerinden Afrikalıların ritüellerine yasaklama getirilmiştir. Köleliğin uzun bir dönem boyunca devam ettiği Osmanlı’nın yıkılarak yerini Cumhuriyete bırakması, yasal düzlemde köleliği yasaklasa da evlatlık uygulamasıyla biçim değiştirerek köleliğin uzantıları devam etmiştir.

Diğer yandan köleler azat edildikten sonra karşılaştıkları sorunlar üzerinde yeteri kadar durulmamaktadır. Osmanlı' daki azatlı kölelerin o zamanlar Aydın vilayetine bağlı olan köylere yerleştirilmesi, bu bölgede Afrikalı topluluğun oluşmasını sağlamıştır; tam nüfusu bilinmeyen azatı köleler, Küçük Menderes Ovası civarında Bayındır, Tire ve Torbalı ilçeleri arasında kalan Yeniçiftlik ve Hasköy gibi köylere yerleştirilmiştir (Erdem, 2013: 226). Bugün İzmir'in farklı köylerinde yaşayan Afro-Türklerin yaşamı, kölelik sonrası yaşamların nasıl devam ettiğinin cevaplarından birini sunmaktadır. 2. Abdülhamit'in çiftliklerine çalışmak üzere köylere yerleştirilen azatlı köleler, yakın köy ve ilçelerde yaşamlarını devam ettirmiş; bir kısmı ise daha iyi iş bulmak umuduyla İzmir başta olmak üzere büyükşsehirlere göç etmiştir. Osmanlı İmparatorluğu'nun yıkılması ve sonrasında kurulan Türkiye Cumhuriyeti'nde kölelikten kaynaklanan sorunları ve ayrımcılık biçimlerini görmek mümkündür. Osmanlı sarayına haremde hizmet ettirilmek üzere gönderilen, orduda, tarımda ve ev işlerinde çalıştırılan kölelerin yerini Türkiye Cumhuriyeti'nde evlerde çalıştırılan evlatlıklar almış ve ev içi emekte hem kadın hem çocuk sömürüsü söz konusu olmuştur.

İnançları ve değerlerine açık ve örtük engeller getirilen Afro-Türkler görünmez olma yoluna giderek kimliklenme sürecini deneyimlemektedirler. Arap, Afro-Türk ve TürkMüslüman olmak üzere üç temel etno-kültürel kimlik kategorisinin benimsendiği gözlemlenmiştir. Bu üç kategori birbirinden mutlak suretle ayrı değildir, çoğu zaman aynı anda kullanılabililmektedir. Bir kimlik kategorisinden ziyade daha çok deri rengini ifade eden bir kategoriye evrilen Arap kelimesi, yaşlı nesil arasında kimi zaman zenci kelimesi ile birlikte 
kullanılmaktadır. Afro-Türk ifadesi ise derneğin açılışıyla kullanıma girmiş ve topluluk için çok yeni bir kavramsallaştırmadır. Afro-Türk ifadesi bir kimlik kategorisi olarak genç kuşak tarafından kabul görse de çoğu kişi için aidiyet kurabilecekleri bir kimlik kategorisi olmaktan uzak görünmektedir. Görünmez olma hali sadece kimlik kategorilerinde değil, aynı zamanda Afro-Türklerin topluluk düzeyinde silikleşen kolektif hatıraları ile de kalıcı olmaktadır. Sadece topluluğun sembolik olarak inşa ettiği etno-kültürel kimlikte ve kolektif hafizada değil; kültürel belleğin en somut görünümü olarak vücut bulan müze ve tarih yazımında da unutulma hali ortaya çıkmaktadır.

Metaforik bir etno-kültürel kimliği görünür bir etno-kültürel kimliğe dönüştürmek isteyen Afrikalılar Kültür, Dayanışma ve Yardımlaşma Derneği, topluluğun geleneklerini canlandırma ve kolektif bellekte silinen izleri diriltme amacıyla hareket etmektedir. Bu amaç, küreselleşme ile yerel kimliklerin görünür kılınmasıyla pekişmekte ve küresel iletişim imkânlarıyla diasporik etkileşimin sağlanarak Afrikalı olmaya dair imajların toplulukta tazelenmesi pratikleriyle birleşmektedir. Ancak, topluluğu Godyalık kurumu gibi hem ruhani hem dünyevi bağlarla bir arada tutacak şekilde derneğin ne derecede ve ne sürede etkili olacağ1, derneğin kuruluşunun 10. yılını doldurduğu 2016 senesi sonrasında da bir soru işareti olarak kalmaktadır. Bu sorunun cevabını ise zaman belirleyecek görünmektedir. Değişime açık olan kimlik inşası düşünüldüğünde, zamanla birlikte farklı bir boyut alabilecek bir etnokültürel kimlikten ve bununla birlikte dönüşecek temsiliyet ve geleneklerden bahsetmemiz mümkün olabilir.

\section{Notlar}

1 Burada bahsedilen, "Afrikalıları insan dışı hayvanlara daha yakın bir yerde konumlandırarak hem onları ayrı bir sınıflandırmaya tabi tutmakta" ifadesi, anaakım kaynaklarda türcü bir ima da içermektedir. Benim kullanımım ise hayvan-insan ikiliğinde insan üstünlüğünü olumlayıcı yaklaşımı kabul etmemektedir. Aksine, insan köleliği ve insan dışı hayvanların köleliği arasındaki benzer meşrulaştırma mekanizmalarının var olduğunu düşünmekteyim.

22006 senesinde kurduğu Afrikalılar Kültür, Dayanışma ve Yardımlaşma Derneği’nin başkanlığını yürüten Mustafa Olpak, 3 Ekim 2016 tarihinde vefat etmiştir. Tez çalışmamı yürütmemde, alana girmemde ve sorularımı cevaplamadaki yardımlarından dolayı kendisine ve Şakir Doğuluer'e teşekkürü borç bilirim.

3 http://t24.com.tr/haber/19-yuzyildan-bu-yana-afro-turkler-arap-zenci-gunduz feneri,205435 [19. Yüzyıldan Bu Yana Afro-Türkler: “Arap”, “Zenci”, “Gündüz Feneri”, 2012] [Erişim Tarihi: 28.10.2014]

4 http://vimeo.com/21088982 [“Arap Kızı Camdan Bakıyor/Baa Baa Black Girl” Belgeseli, 2006 (TRT)] [Erişim Tarihi: 28.10.2014]

5 Mustafa Olpak'ın yüksek lisans tez çalışmam kapsamında 22 Kasım 2015 tarihli görüşmemde bana aktarmış olduğu görüşüdür.

6 Kölelik, Köle Ticareti, Köleliğe Benzer Uygulama ve Geleneklerin Ortadan Kaldırılmasına Dair Ek Sözleşme (http://www.resmigazete.gov.tr/arsiv/11599.pdf) [6 Ocak 1964 tarihli ve 11599 sayılı Resmi Gazete'de yayımlanmıştır.] [Erişim Tarihi: 02.06.2015]

7 Bu bölümde aktarılan ses kayıtlarının hepsi tez çalışmam kapsamında, Şubat 2015-Şubat 2016 zaman aralığında farklı tarihlerde tarafımca gerçekleştirilmiştir. Kişilerin mahremiyetini korumak adına isimler gizlenmiş ve kısaltmalara başvurulmuştur.

8 Bahri Baba ve Susuz Dede isimlerinin ruhani gücü olduğuna inanılan Afrikalı ermiş dedeler olabileceği bilgisini bana Mustafa Olpak vermiştir. 


\section{Kaynaklar}

Boratav, N. P. (1951). The negro in Turkish folklore. (W. Eberhard, Çev.). The Journal of A meric an Folklore. No. 64 (251), ss. 83-88.

Boratav, N. P. (1984). 100 Soruda Türk-folkloru. (2.bs.). İstanbul: Gerçek.

Douglas, M. (2007). Saflk ve tehlike: Kirlilik ve tabu kavramlarının bir çözümlemesi. (E. Ayhan, Çev.). İstanbul: Metis.

Du Bois, B. E. W. (2007). The souls of black folk. (B. H. Edwards, Ed.). Oxford: Oxford University.

Erdem, H. Y. (2013). Osmanlı'da köleliğin sonu 1800-1909. (2. bs.). (B. Tırnakçı, Çev.) İstanbul: Kitap Fanon, F. (2014). Siyah deri, beyaz maske. (C. Koytak, Çev.) (2. bs. ). İstanbul: Versus.

Guess, J. T. (2006). The social construction of whiteness: Racism by intent, racism by consequence. Critical Sociology, No.32 (4), ss. 649-673.

Güntekin, N. R. (2014) [1947]. Miskinler tekkesi. İstanbul: İnkılap.

Hall, S. (1989). New ethnicities. (D. Morley and K.H. Chened, Ed.). (1996). Stuart Hall: C r i t i c a l Dialogues in Cultural Studies, ss. 411-441. London-New York: Routledge.

Hall, S. (2003). The spectacle of the 'other'. (S. Hall Ed.). Representation: Cultural Representations and Cultural Signifying Prctices. (7. bs.). ss. 223-290. London: Sage.

Hirschman, C. (2004). The origins and demise of the concept of race. Population and Development Review, No.30 (3), ss. 385-415.

Hunwick, J. (2004). The religious practices of black slaves in the Mediterranean Islamic world. (içinde) (P. E. Lovejoy, Ed. ) (2004). Slavery on the Frontiers of Islam, ss. 149-171. Princeton: Markus Wiener.

Monteiro, M. N. and Wall, J. D. (2011). African dance as healing modality throughout the diaspora: The use of ritual and movement to work through trauma. The Journal of Pan African Studies, No.4 (6), ss. 234-252.

Olpak, M. (2013). Osmanlı İmparatorluğu'nda köle, Türkiye Cumhuriyeti'nde evlatlı: Afro-Türkler. Ankara Üniversitesi SBF Dergisi (Kronik), No. 68 (1), ss. 123-141.

Soysü, H. (1992). Sudanlılar. Kavimler Kapısı, ss. 54-62. İstanbul: Kaynak.

Şaul, M. (2015). Geçmişten bugüne siyah Afrika'dan Türkiye'ye göçler: Kölelikten küresel girişimciliğe. (M. M. Erdoğan ve A. Kaya Ed.). Türkiye'nin göç tarihi:14. yüzyıldan 21. yüzyıla Türkiye'ye göçler, ss. 77-117. İstanbul: Bilgi Üniversitesi.

Şen, Ö. (2007).Osmanlı'da köle olmak: Esaretten özgürlüğe geçişs süreci. İstanbul: Kap1.

Toledano, R. E. (1993). Late Ottoman concepts of slavery (1830s-1880s). Poetics Today, No.14 (3), ss. 477-506.

Toledano, R. E. (2000). The concept of slavery in Ottoman and other Muslim societies: Dichotomy or continuum. (M. Toru and J. E. Philips, Ed.). Slave elites in the middle east and Africa: A Comparative Study, ss. 159-175. London-New York: Kegan Paul International.

Toledano, R. E. (2007). As if silent and absent-bonds of enslavement in the Islamic middle east. New Haven-London: Yale University.

Uşaklıgil, Z. H. (2005). İzmir hikâyeleri. İstanbul: Özgür.

Uşaklıgil, Z. H. (2010). Sepette bulunmuş-Hepsinden acı. İstanbul: Özgür.

Yelvington, A. K. (1991). Ethnicity as practice: A comment on bentley. Comparative Studies in Society and History, No. 33 (1), ss. 158-168. 


\section{Elektronik kaynaklar}

$<$ http://t24.com.tr/haber/19-yuzyildan-bu-yana-afro-turkler-arap-zenci-gunduz-feneri,205435>

Yüzy1ldan Bu Yana Afro-Türkler: “Arap”, “Zenci”, “Gündüz Feneri”, 2012) (Erişim: 28.10.2014). $<$ http://vimeo.com/21088982> (“Arap K1zı Camdan Bakıyor/Baa Baa Black Girl” Belgeseli, 2006).(TRT). (Erişim: 28.10.2014).

Kölelik, Köle Ticareti, Köleliğe Benzer Uygulama ve Geleneklerin Ortadan Kaldırılmasına

Dair Ek Sözleşme (http://www.resmigazete.gov.tr/arsiv/11599.pdf) (6 Ocak 1964 tarihli ve 11599 sayılı Resmi Gazete'de yayımlanmıştır.) (Erişim: 02.06.2015). 